\title{
Analysis of the Critical Safety Thickness for Pretreatment of Mined-Out Areas Underlying the Final Slopes of Open-Pit Mines and the Effects of Treatment
}

\author{
Zhigang Tao $\mathbb{D}^{1,2}$ Mengnan Li, ${ }^{1,2}$ Chun Zhu ${ }^{10},{ }^{1,2,3}$ Manchao He, ${ }^{1,2,3}$ \\ Xiaohui Zheng, ${ }^{1,2}$ and Shibo $\mathrm{Yu}^{4}$ \\ ${ }^{1}$ State Key Laboratory for Geomechanics and Deep Underground Engineering, Beijing 100083, China \\ ${ }^{2}$ School of Mechanics and Civil Engineering, China University of Mining and Technology, Beijing 100083, China \\ ${ }^{3}$ College of Construction Engineering, Jilin University, Changchun 130026, China \\ ${ }^{4}$ Beijing General Research Institute of Mining \& Metallurgy, Beijing 100083, China \\ Correspondence should be addressed to Chun Zhu; zhuchuncumtb@163.com
}

Received 8 December 2017; Revised 6 February 2018; Accepted 15 February 2018; Published 28 May 2018

Academic Editor: Longjun Dong

Copyright (c) 2018 Zhigang Tao et al. This is an open access article distributed under the Creative Commons Attribution License, which permits unrestricted use, distribution, and reproduction in any medium, provided the original work is properly cited.

\begin{abstract}
Where a mined-out area underlies a slope, it is a direct threat to slope safety and stability. This is of particular concern where a mined-out area underlies the slope of an open-pit mine, and it has a serious impact on the design and safety measures used for the mine. If a mined-out area underlying the final slope of an open-pit mine is not treated adequately and at the appropriate time, it may cause the slip failure of the final slope during the service life of the mine, posing a serious threat to the safety of personnel and equipment during the stripping phase. In light of the potential for such problems, this paper analyzes the instability mode and failure characteristics of an open-pit slope near a mined-out area in China using geological field survey and the polar stereographic projection method. The scale span method, in combination with engineering analogy and consideration of openpit mining technology, is then used to determine the critical safety thickness at which pretreatment of mined-out areas should be carried out. A pretreatment process to infill the mined-out area during construction of open-pit mine steps is put forward, and its effects on slope stability and reliability are comprehensively evaluated. The results show that circular sliding is the most appropriate instability mode for a slope near a mined-out area. The failure initiates through breakage in the roof of the mined-out area, which induces subduction sliding of the free face of the slope at the left boundary of the mined-out area and subsequent failure of the entire regional slope. Comprehensive analysis methods are used to determine that the critical safety thickness at which a mined-out area under the final open-pit slope should be pretreated is $24 \mathrm{~m}$. The recommended treatment countermeasure is to transfer filling slurry into the mined-out area through drilling holes in benches. This can satisfy the stability and reliability requirements for the slope under different working conditions.
\end{abstract}

\section{Introduction}

A large proportion of mining in China uses the open-pit method. Slope stability is a core safety issue at such mines. Illegal mining, which has been on the rise since the 1980s, has resulted in numerous undocumented underground goafs around such mines [1] and these present a clear threat to open-pit mine safety, especially where a mined-out area underlies the open-pit slope and seriously affects slope stability [2-4]. Mining and blasting generate large disturbing shock forces, and the resulting stress redistribution and consequent changes to the engineering geology conditions will affect the internal mechanics of slope failure $[5,6]$. This can cause mined-out areas to collapse instantaneously, directly threatening overall slope stability and the lives of the miners. In recent years, extensive research has been carried out into mined-out areas under slopes with regard to such factors as the influence of the mined-out area on slope stability, the critical safety thickness of the roof of the mined-out area, and treatment methods for the mined-out 
area [7-13]. Hoek proposed that failure would take the form of progressive caving and that steeply dipping slopes are prone to topple when an inclined ore body is mined out; he proposed a limit equilibrium method for slope stability analysis [14]. Brown and Ferguson, meanwhile, analyzed slope stability by taking into account the slope angle, tension cracks, and hydraulic pressure on the shear surface [15]. Li et al. developed a pseudostatic method based on Janbu's Limit Equilibrium Method (LEM) to analyze the influence of dynamic loads from blasting on slope stability [16]. They found that the horizontal loads produced by blast vibrations cause an increase in sliding forces, and this leads to a lower slope stability coefficient. Chai et al. studied the mechanism and degree of influence that mined-out areas located in different parts of open-pit slopes have on the slope stability, using a strength reduction method [17]. Wan proposed applying an accelerating hybrid genetic algorithm to the old slope of a mined-out area under the Jiagou aluminum mine and used FLAC software to analyze the influence of minedout areas of different sizes and locations on the slope stability, evaluating the degree of influence of various factors [18]. Ao et al. used 3D turbulence modeling to determine the flow characteristics of grout and a sequence of multihole grouting. By applying hydromechanical coupling theory, they performed 3D stability analysis based on a geoengineering model to analyze the effectiveness of grouting reinforcement in stabilizing the goaf [19]. Wu et al. evaluated the effects of cemented filling on a mined-out area through the coupling of CMS and 3DMime-FLAC3D based on a scan of the original mined-out area obtained with a CMS 3D mined-out area detection system [20]. Based on uncertainty measurement evaluation and an analytic hierarchy, Dong et al. carried out a comprehensive risk evaluation of underground goafs using multiple indices and found that this method can reduce the risk of accident and improve the mining environment in practice [21]. Another manner by which a mined-out area under an open-pit can be effectively treated is by using the downward deep hole cutting mining caving method of strip mining, as this method does not influence the stability of the final slope.

If the mined-out area underlying the final slope of an open-pit mine is not treated effectively and at the appropriate time, it may cause the slip failure of the final slope during the service life of the mine, posing a serious threat to the safety of personnel and equipment during the stripping phase. Therefore, an assessment of the critical safe roof thickness is urgently required, so that grouting of mined-out areas can be carried out when this critical thickness is reached to ensure overall slope stability. The present study takes the Niukutou open-pit mine in Qinghai Province as an example. The mode of instability and failure characteristics of the slope overlying mined-out areas at this site are analyzed, and the critical safety thickness at which pretreatment of mined-out areas should be conducted is determined synthetically using a variety of methods. Pretreatment measures for mined-out areas are then proposed, and a comprehensive evaluation of the effects of the treatment on slope stability and reliability is carried out, providing a reference for engineering practice at mines where similar conditions pertain.

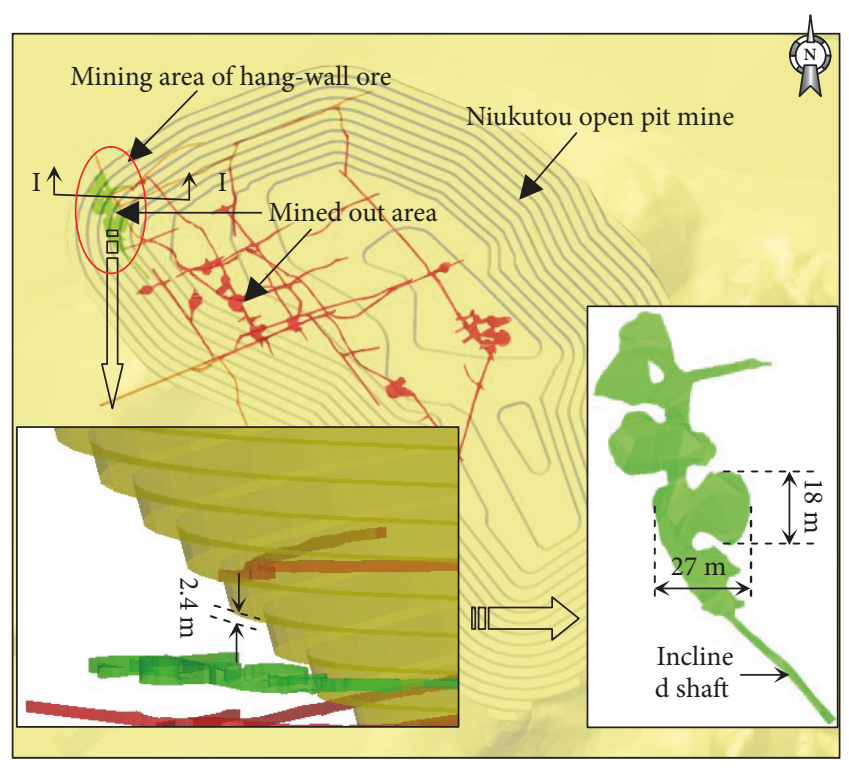

FIGURE 1: Distribution and scale of mined-out areas under Niukutou open-pit mine.

\section{Project Overview}

Niukutou Mine in Qinghai Province is a polymetallic mine that uses open-pit to underground mining. The service life of the open-pit mine is eight years. The main strata lie in a nearly northeast orientation. Lithologically, it is mainly composed of marble, skarn rock (including the ore layer), and granite. This is covered by quaternary alluvial-diluvial glutenite, generally $30-70 \mathrm{~m}$ thick. The mining area is located in the 6-degree earthquake zone.

There are a large number of civil mined-out areas beneath the mining area (Figure 1). The combined volume of the mined-out area is $32,000 \mathrm{~m}^{3}$ under the open-pit as a whole, and $16,000 \mathrm{~m}^{3}$ under the final slope. The mined-out areas are mostly of gallery type. There is a large mined-out area in the northwest of the mine, in the lower part of its final slope. This mined-out area seriously hampers safe production at the mine because it has a major impact on slope stability. On the basis of the results of an existing study [22], the final slope angle recommended by the engineering geology division in this area is $45^{\circ}$.

Because the depth to mined-out areas below the final slope varies, the mined-out area with the largest scale closest to the final slope and with the greatest influence on the stability of the slope is taken as the study area. The length and width of this mined-out area are $27 \mathrm{~m}$ and $18 \mathrm{~m}$, and the area of the roof is approximately $425 \mathrm{~m}^{2}$.

\section{Analysis of the Failure Characteristics of the Slope Overlying a Mined-Out Area}

3.1. Determination of the General Instability Mode of the Slope. There are many groups of joint fissures in the rocky slope rock mass, and the intersection of many such groups with the excavated slope could potentially give rise to a variety of 

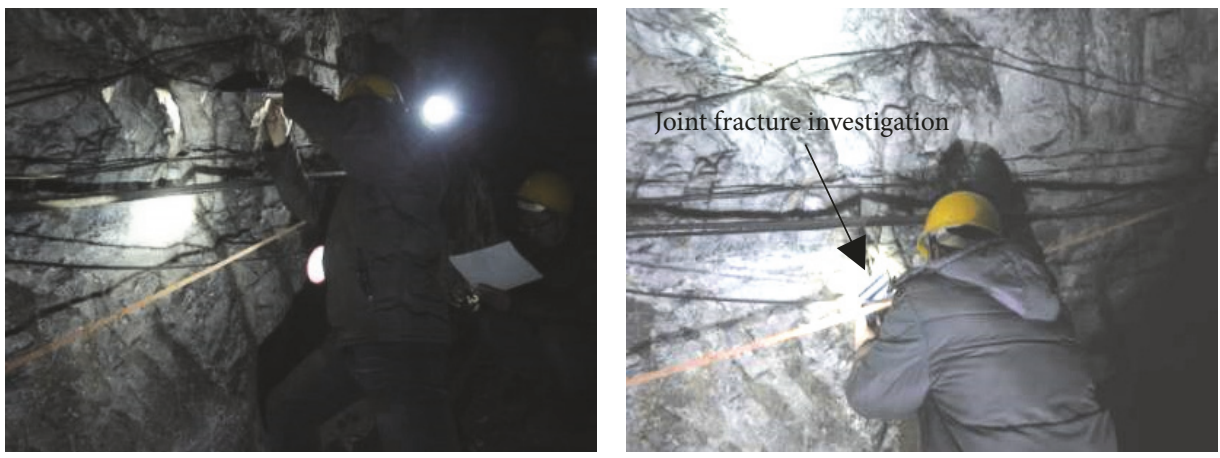

FIGURE 2: Geological field investigation in an inclined shaft in the mined-out area.

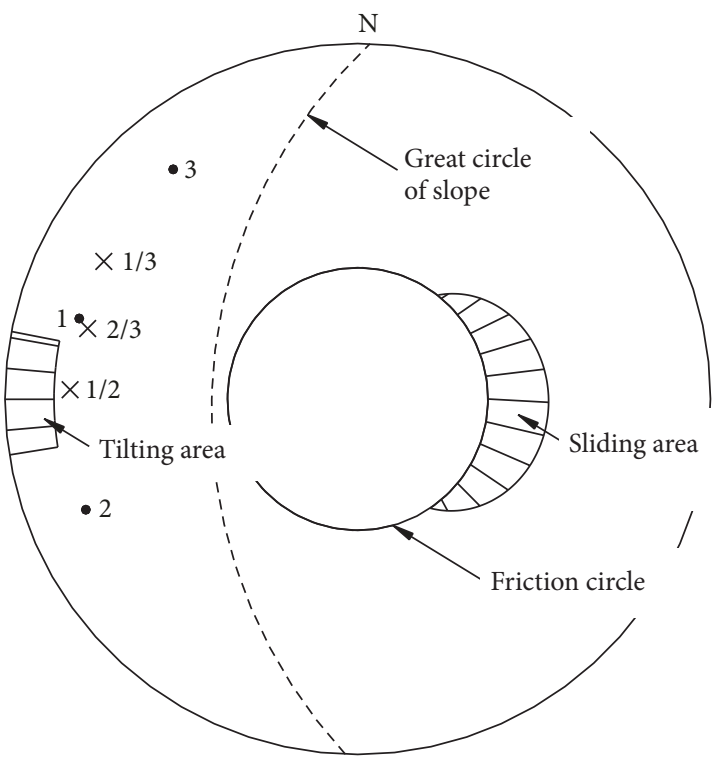

FIGURE 3: Stereographic projection analysis of slope failure mode.

instability modes. Therefore, before a quantitative calculation of slope stability can be undertaken, it is necessary to make a preliminary analysis of the mode of slope failure so that the appropriate stability analysis method can be selected.

The distribution of joints in the rock mass is the decisive factor controlling the stability of a highly jointed rock mass. A geological field investigation was carried out into the occurrence of structural planes in an inclined shaft in the mined-out area using a scanline method, and a statistical analysis of the structural plane and its features was then conducted using the stereographic projection method. The results of these investigations are shown in Table 1 and Figure 2.

The results regarding advantageous joint parameters, slope parameters, and the measured shear strength of the structural plane were summarized $[23,24]$ to achieve a discrimination diagram for the slope failure mode near the mined-out area (Figure 3). The advantageous joint occurrence and intersection of joint surfaces do not fall in the regions indicating a tendency to sliding or tilting, indicating
TABLE 1: Characteristics of structural planes within the study area.

\begin{tabular}{lcc}
\hline $\begin{array}{l}\text { Superior joint group or side } \\
\text { slope number }\end{array}$ & Tendency $^{\circ}$ & Inclination $/^{\circ}$ \\
\hline 1 & 286 & 71 \\
2 & 248 & 72 \\
3 & 321 & 72 \\
I - I profile & 92 & 45 \\
\hline
\end{tabular}

that there is a low probability that plane sliding failure (including plane sliding and wedge sliding) or tilting damage will occur in this area. Because there are three groups of structural planes in the slope rock mass, there is no group of structural planes that would be advantageous for tilting. As it can be considered that the rock mass is isotropic and the Proctor hardness coefficient of the marble composing the main rock mass of the slope is small $(\mathrm{f}=5)$ when the scale of the side slope is relatively large, a combination of discrimination standards for slope instability models $[25,26]$ indicates that the slope in this area will fail by circular sliding.

3.2. Mechanical Parameters of the Rock Mass. In light of the mode of slope failure identified, the selection of the mechanical parameters of the rock mass has a serious impact on the reliability of the slope stability analysis. Therefore, it is important to determine reasonable mechanical parameters to be used for this purpose.

The standard recommended methods were used [25]. The Feixinke Method, Georgi Method, experience reduction method, proposed RMR method, comparison of structural plane and rock strength, Hoek-Brown strength criterion (2002), and engineering analogy were used to comprehensively determine the shear strength index of the rock mass within the scope of the study [27]. Specific parameters can be seen in Table 2.

3.3. Evolution of the Slope Failure. On account of the failure mode identified, Phase 27.0 and Slide 6.0 software were used to analyze the process of slope failure when underlain by a mined-out area. The results are shown in Figure 4.

The process of failure calculated using the strength reduction method of Phase2 7.0 and the simplified Bishop 


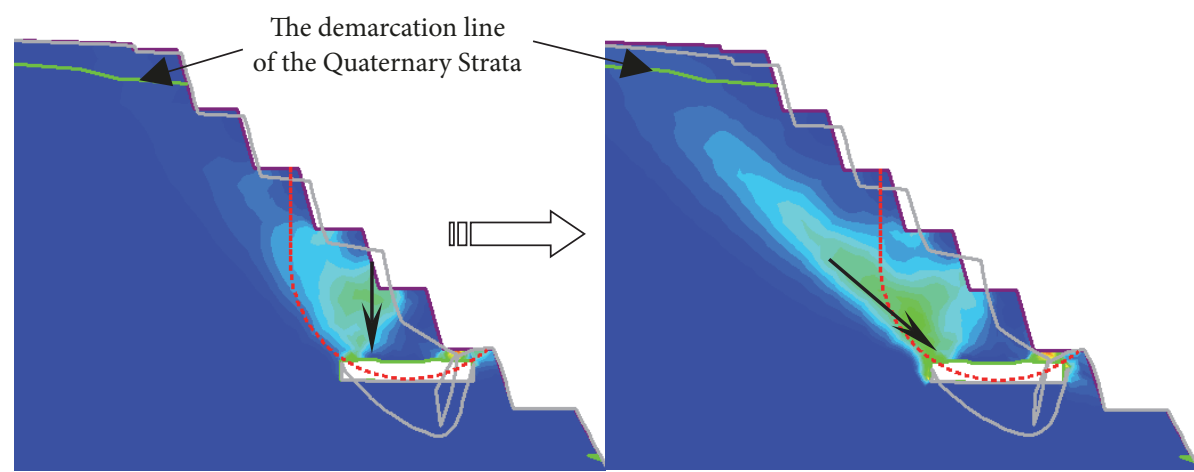

- - - Calculation curve with the Simplified bishop method

_ Failure curve of slope and crown pillar

(a) Instability of crown pillar
- - - Calculation curve with the Simplified bishop method

_ Failure curve of slope and crown pillar

(b) Slope sliding

FIgURE 4: Evolution of the failure of a slope overlying a mined-out area.

TABLE 2: Physical and mechanical parameters of rock mass and soil.

\begin{tabular}{lccc}
\hline $\begin{array}{l}\text { Type of rock } \\
\text { mass and soil }\end{array}$ & $\begin{array}{c}\text { Weight } \gamma \\
/ \mathrm{kN} / \mathrm{m}^{3}\end{array}$ & $\begin{array}{c}\text { Cohesion c } \\
/ \mathrm{kPa}\end{array}$ & $\begin{array}{c}\text { Angle of internal friction } \varphi \\
/^{\circ}\end{array}$ \\
\hline Quaternary & 18.7 & 27 & 25 \\
Marble & 26.5 & 90 & 31 \\
Skarn & 37.6 & 170 & 32 \\
Granite & 26.4 & 180 & 33 \\
Filling & 20.0 & 85 & 27 \\
\hline
\end{tabular}

method of Slide 6.0 is consistent. Namely, failure occurs by fracturing of the roof of the mined-out area, which causes subduction sliding of the free face of the slope at the left side of the mined-out area, leading to slope failure across the whole area. Therefore, the existence of the mined-out area seriously affects the stability of the slope, and relevant pretreatment measures must be taken to deal with the mined-out area.

\section{Determination of the Critical Safety Thickness for Pretreatment of the Mined-Out Area}

Treatment of the mined-out area must be carefully timed so that it does not affect production but guarantees the stability of the slope during the production process. Therefore, it is necessary to determine the critical thickness at which the mined-out area should be pretreated.

There have been studies into the safe thickness for the roof (crown pillar) of a mined-out area, in both China and elsewhere, using approaches such as the load transfer line intersection method, span-to-depth ratio method, broken arch theory method, Rubienie Yite theory estimation method, and Bogoliubov theory calculation method. These methods are mainly based on single geometric parameters relating to the span of the mined-out area and so have certain limitations. On the basis of data from more than 300 boundary crown pillars, Carter et al. proposed the scaled span method, which determines the critical safety thickness for the roof of a mined-out area based on its geometrical parameters and the dip angle of the orebody in the mined-out area [28-30]. This method can estimate the safety coefficient, service term, and probability of failure of roofs of different thicknesses, and abundant use has proven its practicability, safety, and scientificity. This paper analyzes the critical safety thickness for pretreatment of the mined-out area using the scaled span method and engineering analogy with similar open-pit mines in China and abroad.

4.1. Scaled Span Method. The key to using the scaled span method to determine a safe thickness for the roof is to determine the scaled span of the crown pillar. The calculation formula is as follows:

$$
C_{S}=S\left[\frac{\gamma}{T\left(1+S_{R}\right)(1-0.4 \cos \theta)}\right]^{0.5} .
$$

$C_{S}$ is the scaled span of the crown pillar in meters; $S$ is the actual span of the crown pillar, here $18 \mathrm{~m} ; \gamma$ is the rock mass weight, which is $2.7 \mathrm{t} / \mathrm{m}^{3} ; T$ is the actual thickness of the crown pillar in meters; $\theta$ is the dip angle of the ore body, which is $90^{\circ}$; and $S_{R}$ is the span ratio $S / L$, which is $18 / 27$.

$$
S_{c}=3.3 Q^{0.43}[\sinh (Q)]^{0.0016} .
$$

$S_{C}$ is the critical scaled span in meters; $Q$ is the $Q$ value obtained using the Q-system classification method, which, 
according to the geological field investigation of the connecting shaft of this mined-out area and adjusted on the basis of the results of supplementary drilling, is 6.913; and $\sinh ()$ is the hyperbolic sine function.

The probability $P_{f}$ of failure of crown pillars of different thicknesses is calculated using $F_{C}$, the safety coefficient of the crown pillar, which can be calculated as

$$
F_{C}=\frac{S_{C}}{C_{S}}
$$

The formula for $P_{f}$ is then

$$
P_{f}=1-\operatorname{erf}\left[\frac{2.9 F_{C}-1}{4}\right]
$$

where $P_{f}$ is the probability of failure and erf[]is the error function. This formula has a high accuracy for estimating the probability of failure when $P_{f}<<50 \%$ and $F_{C}>1$.

The relationship between the thickness of the crown pillar, the safety coefficient of the crown pillar for pretreatment at Niukutou Mine, and the failure probability as determined using the above formula is shown in Figure 5.

As shown in Figure 5, with an increase in the thickness of the crown pillar, the safety coefficient, $\mathrm{F}_{c}$, increases and the probability of failure, $\mathrm{P}_{\mathrm{f}}$, decreases. If strip mining is carried out in accordance with the original design scheme, the final thickness of the crown pillar is $2.4 \mathrm{~m}$, which has a safety coefficient of only 0.58 and a probability of failure as high as $85.1 \%$, far in excess of stability requirements. According to the requirements for the stability of the crown pillar under similar conditions using the scaled span method, the safety coefficient must be above 1.5 , and the critical safety thickness of the roof determined thereby is $20.2 \mathrm{~m}$, giving a probability of failure of $23.6 \%$.

4.2. Engineering Analogy Method. Engineering analogy has frequently been used to determine the safe thickness of a mined-out area roof in China and abroad, and a large number of engineering examples have therefore become available. Mines with a similar span and extent of minedout area, slope scale, and rock lithology as Niukutou Mine were selected for statistical analogy and are listed in Table 3. The safe thicknesses of the crown pillars of these mines are obtained using the Rubienie Yite theory estimation method and engineering experience. Through engineering analogy, the critical safety thickness of the roof of the mined-out area is $15-25 \mathrm{~m}$.

4.3. Comprehensive Determination of Critical Safety Thickness for Pretreatment. The safe thickness of the roof determined by the scaled span method and engineering analogy is essentially the same. To reduce the impact that pretreatment of the mined-out area has on production and considering that strip mining at Niukutou Mine uses a step height of $12 \mathrm{~m}$, the critical safety thickness for pretreatment of the mined-out area under the slope is $24 \mathrm{~m}$. This means that pretreatment should be conducted two steps ahead.

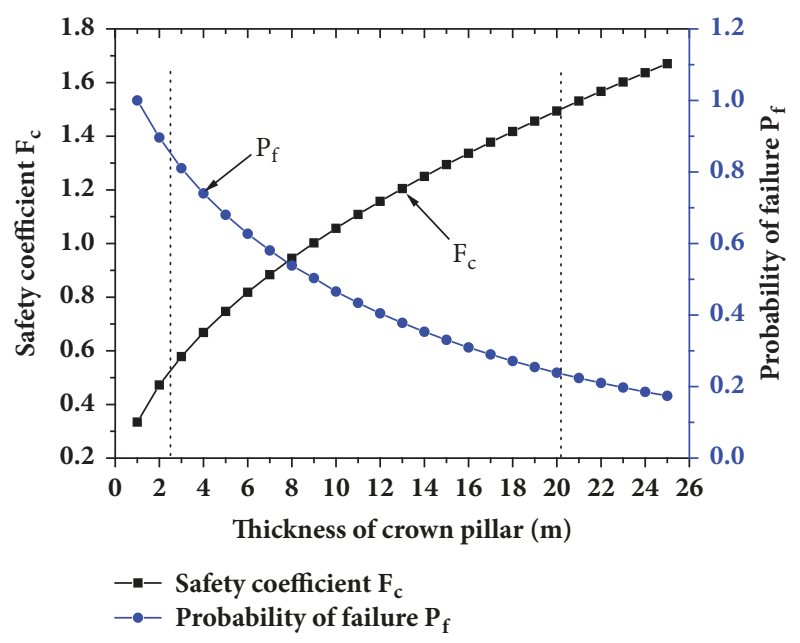

FIGURE 5: The relationships between the thickness of the crown pillar and both the safety factor and probability of failure.

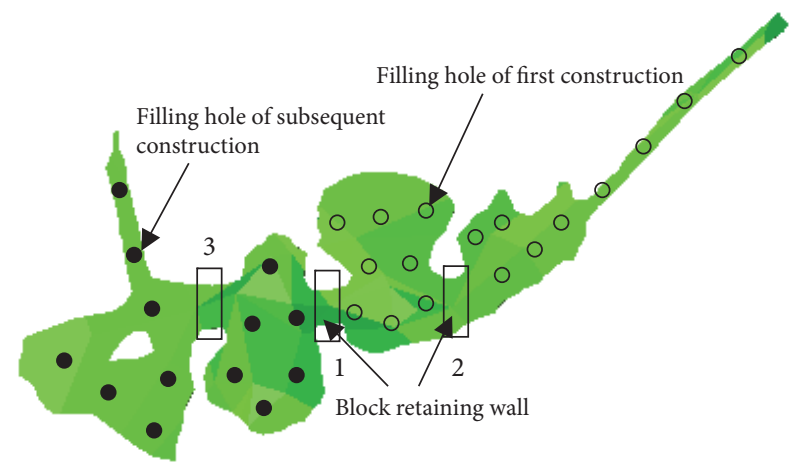

$\square$ Block retaining wall

O Filling hole of first construction

- Filling hole of subsequent construction

FIgURE 6: Treatment scheme for the mined-out area under the final slope of the open-pit mine.

\section{Analysis of the Effect of Pretreatment of the Mined-Out Area}

5.1. Pretreatment Strategy. The selection of pretreatment strategy has a decisive effect on the stability of the openpit slope. After a comprehensive comparison of a variety of treatment methods, the method that has been adopted is to fill the mined-out area is to discharge filling slurry into drill holes during step construction (Figure 6). This method has the advantages of improving the load-bearing status of the rock mass surrounding the mined-out area and increasing the shear strength of the potential sliding surface of the mined-out area, playing an "antisliding" role. The treatment measures are as follows:

(1) General principles: the initial area to be filled and areas for subsequent filling are divided according to the critical depth at which pretreatment is required. Concrete block retaining wall 1 is constructed between the two areas to ensure 
TABLE 3: Statistics of boundary pillar thickness in comparable mines.

\begin{tabular}{lccc}
\hline Name of mines & $\begin{array}{c}\text { Span of mined-out } \\
\text { area/m }\end{array}$ & $\begin{array}{c}\text { Area of mined-out } \\
\text { area/m }\end{array}$ & $\begin{array}{c}\text { Safety thickness of crown } \\
\text { pillar/m }\end{array}$ \\
\hline Krivoy Rog Mine & $15-25$ & $200-600$ & $20-30$ \\
Haydargangski Mine & $25-30$ & $100-500$ & $15-20$ \\
Nuosisiji Chai Mine & - & $200-2100$ & $14-16$ \\
Niki Torfs Ki Mine & $20-25$ & - & $15-30$ \\
Datang Mine & 20 & - & 15 \\
Chuanyandong Mine & $20-25$ & - & 24 \\
Jinchangyu Mine & $>20$ & - & 25 \\
Shirengou iron Mine & 20 & & 20 \\
\hline
\end{tabular}

TABLE 4: The slope stability safety factor and probability of slope failure under different working conditions.

\begin{tabular}{|c|c|c|c|}
\hline \multirow{3}{*}{ Working conditions } & \multicolumn{3}{|c|}{ Calculation method } \\
\hline & \multicolumn{2}{|c|}{ Safety coefficient } & \multirow{2}{*}{ Failure probability } \\
\hline & Simplified Bishop method & Strength reduction method & \\
\hline \multicolumn{4}{|l|}{ Unfilled mined-out area } \\
\hline No earthquake force & 0.756 & 0.49 & $100 \%$ \\
\hline Earthquake force & 0.747 & 0.49 & $100 \%$ \\
\hline \multicolumn{4}{|l|}{ Filled mined-out area } \\
\hline No earthquake force & 1.169 & 1.13 & $0.2 \%$ \\
\hline Earthquake force & 1.145 & 1.10 & $0.4 \%$ \\
\hline
\end{tabular}

the quality and effectiveness of filling, and concrete block retaining walls 2 and 3 are constructed subsequently. The filling area that has the largest influence on the slope should be filled first, before the critical treatment depth is reached and then, for areas that have a smaller influence on the slope, it can subsequently be determined whether and when filling should be carried out.

(2) Blocking measures: a hole of the same diameter as the blasting hole is drilled down at the center of the blocking position. C20 concrete is injected into the minedout area until the concrete fills the whole drilling hole. Several holes are then drilled adjacent to the filled drilling hole to test the blocking effect. If some locations are not blocked satisfactorily, more C20 concrete can be added until the hole is filled. Accelerator can be added to ensure that the concrete in the mined-out area solidifies as quickly as possible.

(3) Filling measures: backfill drilling holes with a spacing of $10-15 \mathrm{~m}$ are drilled in the area to be filled and filling slurry is discharged into them. Depending on the actual filling effect, the spacing of the backfill drilling holes can be densified to ensure that the filling body fully contacts the roof. When the filling slurry reaches the top of each backfill drilling hole, the filling of the hole can be considered complete. A mixer is used to mix the filling slurry of cemented tailings uniformly, and the pressure difference at the mixer is used to flow the filling slurry into the mined-out area.

(4) Requirements for filling slurry: on the basis of indoor test results of a mine-filling body under similar lithological conditions and engineering geological conditions [31], when cemented tailings are used as filling materials and the cement-sand ratio is 1:6, the concentration of filling slurry can reach above $70 \%$ after filling without emitting water.

5.2. Stability Evaluation. The pretreatment measures directly affect the stability of the slope near the mined-out area. The failure mode near the mined-out area was preliminarily determined to be circular sliding. On the basis of a combination of related standards $[25,26,32]$, slope stability was analyzed using the simplified Bishop limit equilibrium method and the strength reduction method. The results regarding slope stability under different working conditions are shown in Table 4.

The two methods both indicate that the safety coefficient of the slope when the mined-out area is not treated is much less than 1.0: the slope cannot be kept stable. When pretreatment filling of the mined-out area is carried out, the slope stability is greatly improved, meeting the requirements that the safety coefficient of the slope over the service life is not less than 1.15 and the safety coefficient of slope under earthquake force is not less than $1.10[32,33]$. Thus, this slope pretreatment strategy is reasonable and practical and meets the slope stability requirements.

5.3. Reliability Evaluation. Due to the specific characteristics of the rock itself, the shear strength index has a certain variability. Therefore, the influence of the random distribution of the shear strength index on the analysis of slope stability must be considered. A large number of studies have shown that the probability density function of the shear strength 


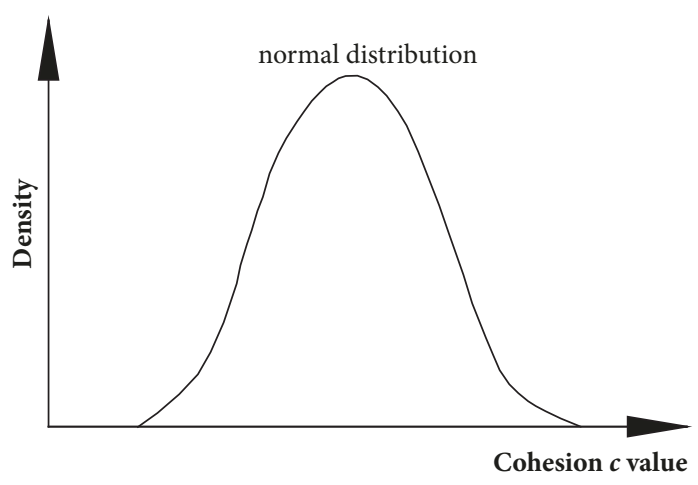

(a) Cohesion $c$

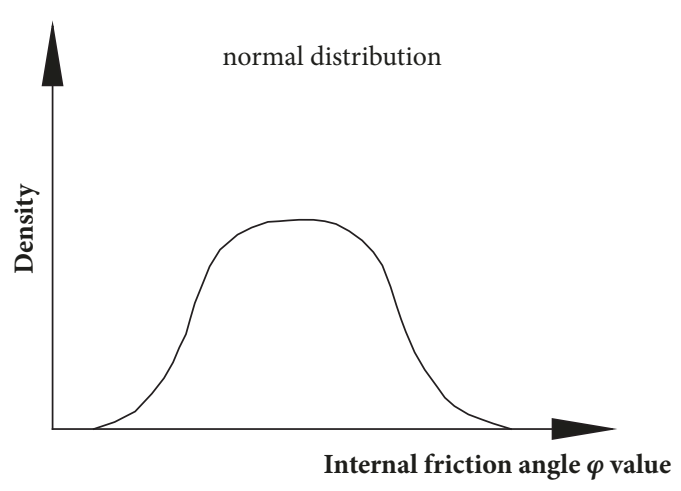

(b) Internal friction angle $\varphi$

FIgURE 7: Typical probability density functions of shear strength index.

index, which plays a key role in slope stability analysis, has a normal distribution or an approximately normal distribution (Figure 7). Another key problem in slope reliability analysis is to determine the value of the minimum shear strength index. Through engineering analogy, comparison of the shear strength parameters of interior structures, and other methods, the lower limit of the shear strength index is determined to be $\mathrm{c}=40 \mathrm{kPa}, \varphi=25^{\circ}$. Taking the shear strength parameters of the rock mass in Table 2 as the average values and $c=40 \mathrm{kPa}$ and $\varphi=25^{\circ}$ as the average value to deduct the lower limit value of a probability density function of 3 times the standard deviation, the taking value interval is up to a confidence level of $99.74 \%$.

The analysis of slope reliability was carried out with Slide 6.0 slope stability analysis software and the Monte Carlo method, running 1,000 cycles. As shown in Table 4, the probability of failure of the slope is $100 \%$ when the mined-out area is not pretreated, but after filling, even under earthquake force, the probability of slope failure meets the reliability requirement that the probability of slope failure at an open-pit mine must be [34] $0.3 \%-1.0 \%$. Thus, slope reliability is better after the mined-out area has been filled.

\section{Conclusions}

(1) At Niukutou Mine in China, structural plane occurrence, the slope, and the structural planes together indicate that a slope overlying a mined-out area will fail by near-circular arc sliding.

(2) Slope failure develops through breaking of the roof of the mined-out area, subduction sliding failure of the free face of the slope along the left boundary of the mined-out area, and then slope failure across the whole area.

(3) The comprehensive scaled span method, engineering analogy, and the parameters of Niukutou Mine's stepped slope design are used to determine that the critical safety thickness for pretreatment of the mined-out area under the slope is 24 $\mathrm{m}$.

(4) The mined-out area under the slope can be filled by discharging filling slurry into backfill drilling holes during step construction. This treatment meets requirements regarding slope reliability and the slope safety coefficient under different conditions.

\section{Conflicts of Interest}

The authors declare that they have no conflicts of interest.

\section{Authors' Contributions}

Dr. Zhu proposed the idea of this article, and Dr. Tao and Dr. Zhu completed the first draft of this article together. Zhigang Tao and Chun Zhu contributed equally to this work. Since the later revision work was mainly completed by Chun Zhu, all authors agreed that Dr. Tao and Dr. Zhu can serve as co-first authors.

\section{Acknowledgments}

This work is supported by the National Natural Science Foundation of China (no. 41502323 and no. 41602365) and Beijing Natural Science Foundation of China (8142032).

\section{References}

[1] Y.-P. Zhang, P. Cao, H.-P. Yuan, and L.-J. Dong, "Numerical simulation on stability of complicated goaf," Journal of Mining and Safety Engineering, vol. 27, no. 2, pp. 233-238, 2010.

[2] K.-S. Woo, E. Eberhardt, D. Elmo, and D. Stead, "Empirical investigation and characterization of surface subsidence related to block cave mining," International Journal of Rock Mechanics and Mining Sciences, vol. 61, no. 61, pp. 31-42, 2013.

[3] Y. Yin, P. Sun, M. Zhang, and B. Li, "Mechanism on apparent dip sliding of oblique inclined bedding rockslide at Jiweishan, Chongqing, China," Landslides, vol. 8, no. 1, pp. 49-65, 2011.

[4] Y. Yin and A. Xing, "Aerodynamic modeling of the Yigong gigantic rock slide-debris avalanche, Tibet, China," Bulletin of Engineering Geology and the Environment, vol. 71, no. 1, pp. 149160, 2012.

[5] M. Marschalko, I. Yilmaz, M. Bednárik, and K. Kubečka, "Influence of underground mining activities on the slope deformation genesis: Doubrava Vrchovec, Doubrava Ujala and Staric case 
studies from Czech Republic," Engineering Geology, vol. 147-148, no. 15, pp. 37-51, 2012.

[6] M. L. Sabino, "Numerical modeling of failure mechanisms in phyllite mine slopes in Brazil," International Journal of Rock Mechanics \& Mining Sciences, vol. 24, no. 6, pp. 777-782, 2014.

[7] C. Sagaseta, J. M. Sánchez, and J. Cañizal, "A general analytical solution for the required anchor force in rock slopes with toppling failure," International Journal of Rock Mechanics and Mining Sciences, vol. 38, no. 3, pp. 421-435, 2001.

[8] C. H. Liu, M. B. Jaksa, and A. G. Meyers, "Improved analytical solution for toppling stability analysis of rock slopes," International Journal of Rock Mechanics and Mining Sciences, vol. 45, no. 8, pp. 1361-1372, 2008.

[9] A. K. Alzoubi, C. D. Martin, and D. M. Cruden, "Influence often sile strength on toppling failure in centrifuge tests," International Journal of Rock Mechanics \& Mining Sciences, vol. 47, no. 6, pp. 974-982, 2010.

[10] A. Majdi and M. Amini, "Analysis of geo-structural defects in flexural toppling failure," International Journal of Rock Mechanics and Mining Sciences, vol. 48, no. 2, pp. 175-186, 2011.

[11] F. Agliardi, G. B. Crosta, F. Meloni, C. Valle, and C. Rivolta, "Structurally-controlled instability, damage and slope failure in a porphyry rock mass," Tectonophysics, vol. 605, no. 605, pp. 3447, 2013.

[12] D. Xuan and J. Xu, "Grout injection into bed separation to control surface subsidence during longwall mining under villages: Case study of Liudian coal mine, China," Natural Hazards, vol. 73, no. 2, pp. 883-906, 2014.

[13] X. B. Li, L. J. Dong, G. Y. Zhao et al., "Stability analysis and comprehensive treatment methods of landslides under complex mining environment-a case study of Dahu landslide from Linbao Henan in China," Safety Science, vol. 50, no. 4, pp. 695704, 2012.

[14] E. Hoek, "Progressive caving induced by mining an inclined ore body," Transactions of the Institution of Mining and Metallurgy, vol. 83, pp. 133-139, 1974.

[15] E. T. Brown and G. A. Ferguson, "Progressive hanging wall caving at Gath's mine, Rhodesia," Transactions of the Institution of Mining and Metallurgy, vol. 88, pp. 92-105, 1979.

[16] L. Ma, K. Li, S. Xiao, X. Ding, and S. Chinyanta, "Research on effects of blast casting vibration and vibration absorption of presplitting blasting in open cast mine," Shock and Vibration, vol. 2016, Article ID 4091732, 9 pages, 2016.

[17] H.-B. Chai, P. Cao, G.-W. Chai, and H. Lin, "Influence of goaf on slope stability," Journal of Central South University (Science and Technology), vol. 41, no. 4, pp. 1528-1534, 2010.

[18] W. Wen, Study on the influence of underground mined out area on slope stability, Central South University, Changsha, China, 2006.

[19] X. Ao, X. Wang, X. Zhu, Z. Zhou, and X. Zhang, "Grouting simulation and stability analysis of coal mine goaf considering hydromechanical coupling," Journal of Computing in Civil Engineering, vol. 31, no. 3, Article ID 4016069, 2016.

[20] S. Wu, W. Song, J Du et al., "Stability of numerical simulation and security monitoring of filling method to mining the hanging wall ore on high-steep slope," Journal of Mining \& Safety Engineering, vol. 30, no. 6, pp. 876-879, 2013.

[21] L. Dong, W. Shu, X. Li, Z. Zhou, F. Gong, and X. Liu, "Quantitative evaluation and case study of risk degree for underground goafs with multiple indexes considering uncertain factors in mines," Geofluids, vol. 2017, Article ID 3271246, 15 pages, 2017.
[22] W. Zhou, L. Han, J. Shu, and Q. Meng, "Research on stability control mechanism of concave slope with circular sliding mode," Journal of China University of Mining and Technology, vol. 45, no. 1, pp. 70-76, 2016.

[23] B. Tian, X. Lu, Y. Huang, and D. Jiang, "Excavation disturbance and its influential factors on material-yard slope of Guandi hydropower station in Yalong River," Chinese Journal of Rock Mechanics and Engineering, vol. 29, Supement 1, pp. 3199-3207, 2010.

[24] C. Zuyu, W. Xiaogang, Y. Jian et al., Stability Analysis of Rock Slope-Principle, Method and Procedure, China Water Conservancy and Hydropower Press, Beijing, China, 2005.

[25] Ministry of Housing and Urban-Rural Development. GB/T50330-2013 Technical Specifications for Building Slope Engineering, China Building Industry Press, Beijing, China, 2014.

[26] Ministry of Water Resources of the People's Republic of China, SL386-2007 Slope Design Specification for Water Conservancy and Hydropower Project, China Water Conservancy and Hydropower Press, Beijing, China, 2007.

[27] H. Chen, C. Hui, Y. Shibo et al., Research Report of Rock Mechanics of Mining Engineering in Iron Polymetallic Ore in M1 Magnetic Anomaly Zone of Niukutou Mine, Beijing General Research Institute of Mining and Metallurgy, Beijing, China, 2014.

[28] T. G. Carter and R. I. Miller, "Crown pillar risk assessment - planning aid for cost-effective mine closure remediation," Transactions of the Institution of Mining and Metallurgy, no. 104, pp. A41-A57, 1995.

[29] T. G. Carter, "An update on the scaled span concept for dimensioning surface crown pillars for new or abandoned mine workings," in Proceedings of the 4th North American Rock Mechanics Conference, pp. 465-472, Seattle, Wash, USA, 2000.

[30] D. J. Hutchinson, C. Phillips, and G. Cascante, "Risk considerations for crown pillar stability assessment for mine closure planning," Geotechnical and Geological Engineering, vol. 20, no. 1, pp. 41-63, 2002.

[31] X. Wenyuan, Y. Chao, G. Lijie et al., Research on the High Altitude And Large Flow Filling Technology of Jiama Copper Polymetallic Deposit, Beijing General Research Institute of Mining and Metallurgy, Beijing, China, 2014.

[32] Ministry of Housing and Urban-Rural Development, GB508302013 Design Code for Metallurgical Mining, China Planning Press, Beijing, China, 2013.

[33] P. Darling, SME engineering handbook, Society for Mining, Metallurgy, and Exploration, Englewood, Colo, USA, 3rd edition, 2011.

[34] Z. Yuxue, Slope reliability analysis, Metallurgical Industry Press, Beijing, China, 1993. 


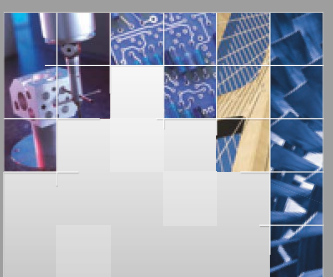

\section{Enfincering}
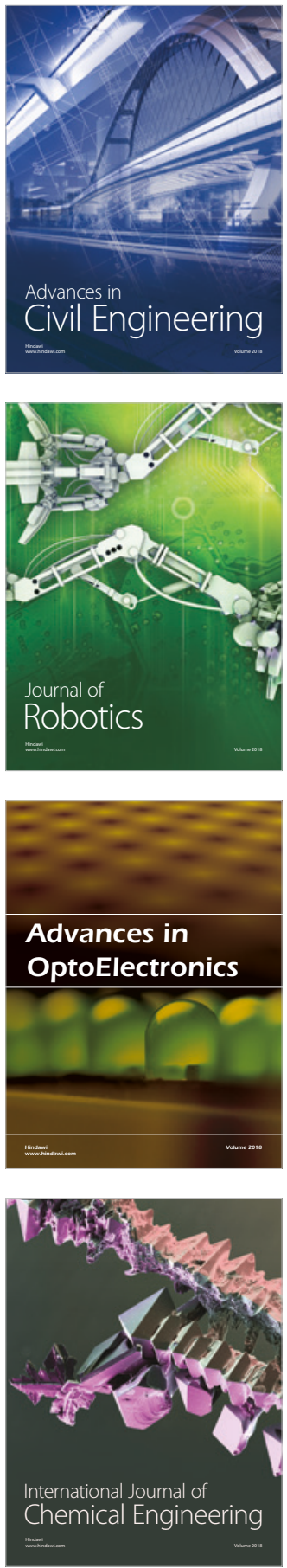

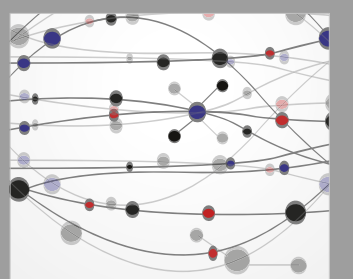

\section{Rotating \\ Machinery}

The Scientific World Journal

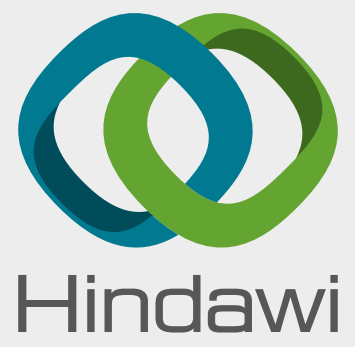

Submit your manuscripts at

www.hindawi.com
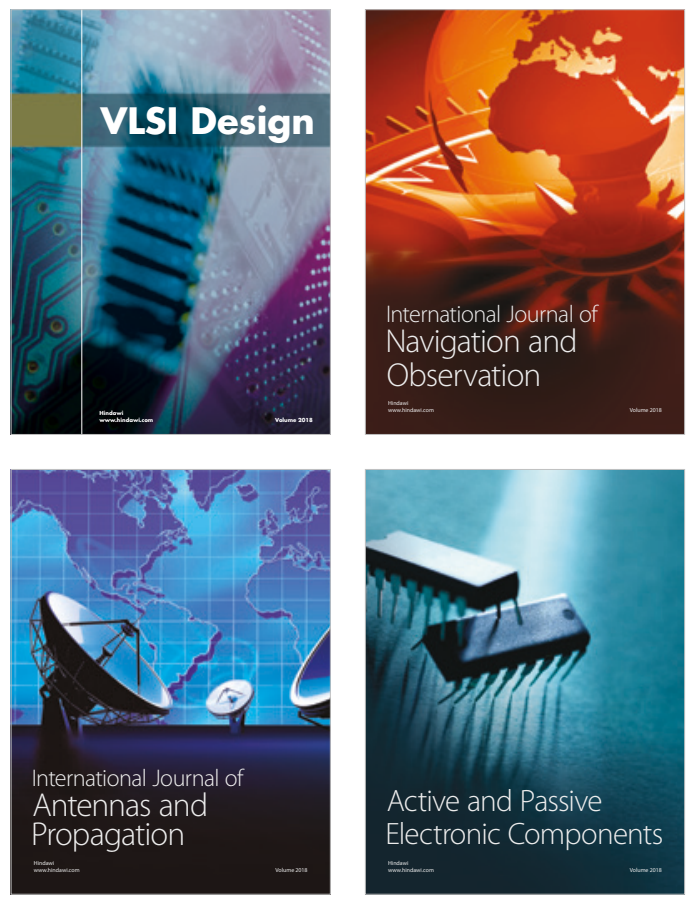
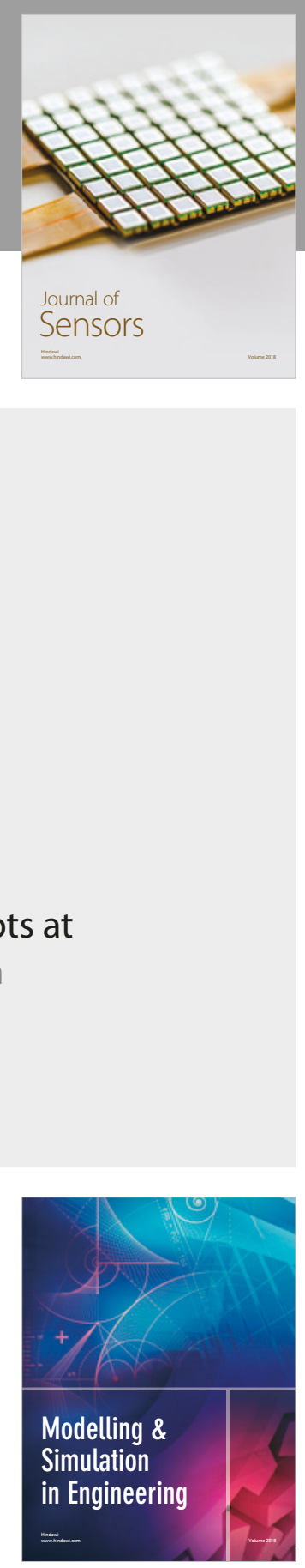

\section{Advances \\ Multimedia}
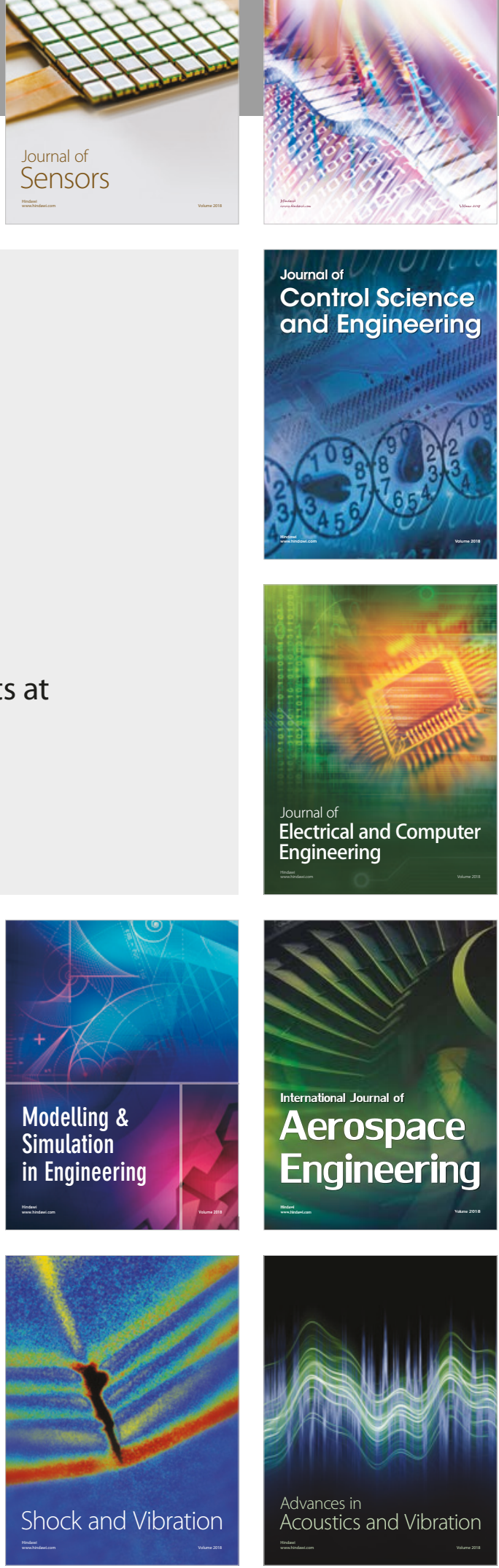